\title{
Erratum to: Opicapone: A Review in Parkinson's Disease
}

\author{
Lesley J. Scott ${ }^{1}$
}

Published online: 3 September 2016

(c) Springer International Publishing Switzerland 2016

\section{Erratum to: Drugs (2016) 76:1293-1300 \\ DOI 10.1007/s40265-016-0623-y}

The author has alerted us to the following error:

Page 1299, Sect. 7, paragraph 2, line 6: the line previously read:

"placebo, adjunctive entacapone $50 \mathrm{mg} /$ day was shown to be"

should read:

"placebo, adjunctive opicapone $50 \mathrm{mg} /$ day was shown to be"

The online version of the original article can be found under doi:10.1007/s40265-016-0623-y.

Lesley J. Scott

demail@springer.com

1 Springer, Private Bag 65901, Mairangi Bay, 0754 Auckland, New Zealand 